\title{
Thinking beyond Secularism: The Catholic Church and Political Practice in Rural South India
}

\section{Aparna Sundar}

\section{OpenEdition}

\section{Journals}

Electronic version

URL: http://journals.openedition.org/samaj/3368

DOI: $10.4000 /$ samaj.3368

ISSN: 1960-6060

\section{Publisher}

Association pour la recherche sur l'Asie du Sud (ARAS)

\section{Electronic reference}

Aparna Sundar, «Thinking beyond Secularism: The Catholic Church and Political Practice in Rural South India », South Asia Multidisciplinary Academic Journal [Online], Free-Standing Articles, Online since 19 April 2012, connection on 19 April 2019. URL : http://journals.openedition.org/samaj/3368 DOI : 10.4000/samaj.3368

This text was automatically generated on 19 April 2019

\section{cc)}

This work is licensed under a Creative Commons Attribution-NonCommercial-NoDerivatives 4.0

International License. 


\title{
Thinking beyond Secularism: The Catholic Church and Political Practice in Rural South India
}

\author{
Aparna Sundar
}

1 In recent years, the notion that the world is inexorably moving towards secularisation has been effectively laid to rest, with the rise of a religious right in the United States, the growing reach of Pentecostalism across the world, the spread of political Islamic movements across Asia and Africa (Casanova 1996, Gorski \& Altinordu 2008, Freedman 2009, Mahmood 2004). Within India, the rise of the Bharatiya Janata Party, with its claim to represent the Hindu majority, as well as the issues it has raised vis-à-vis other religions, such as Christian conversion and Muslim adherence to personal law instead of a common civil code (Jaffrelot 1996, Bhatt 2001) have sparked a series of analytical and normative debates about the nature of Indian secularism (Bhargava 1998, Tejani 2008, Srinivasan 2007, Needham \& Sunder Rajan 2007). On political platforms the debate has been waged between those who advocate a strict separation of religion and state (the leftliberal position), to those who argue that Indian secularism has meant a tolerance of all religions and equal respect and patronage for them by the state, to those who argue for a form of Hindu theocracy (Tejani 2008: 7-11).

In academic terms, the lines have been drawn most sharply between T.N. Madan and Ashish Nandy, on the one hand, who argue that secularism is alien to India, where all the major religions have prioritised religion over politics, and comes from Protestantism and its particular relationship to science and state (Madan 1998, Nandy 1998), and Rajeev Bhargava who argues for a distinctive form of Indian secularism, based not on rigid separation, but a 'principled distance' between religion and state, based on contextual moral reasoning about what each religion required and how this fitted in with the lines that the state had demarcated for itself (Bhargava 2007). Thus if Christians feel the need for conversion, while no other religion does, or Muslims feel the need for their own personal law in some spheres, a secular state would recognise these imperatives and balance them with the interests of others. While the Madan/Nandy argument has been 
criticised, not least because it does not reflect the trajectory of European or American secularism (Archer 2001), Bhargava's approach runs the risk of focusing too much on the state, and not adequately looking at forces within religion itself which may be driving certain kinds of secularism and democratisation (Nigam 2006, Tejani 2008).

3 Sociological attention to the forces driving secularism and democratisation within religions, and more broadly to the ways in which religion interacts with politics, has been limited, in what has often been a theoretical debate around secularism. This neglect is especially striking with regard to the 'minority' communities outside the main-frame of Hindu nationalism, with some honourable exceptions (essays in Saberwal \& Hasan 2006). We still know little about new forms of religious subjectivity, about struggles around representation, and about larger national and transnational influences on religious practice, identity and political assertion within such communities.

This article breaks new ground by looking at politicised Christianity and its role in creating certain kinds of citizens. ${ }^{1}$ I argue that debates over secularism need to look at the ways in which particular religions construct the good life, and if, or the extent to which, this comes into conflict with secular ideals. I look at the way in which the Catholic Church in Kanyakumari mediates the relationship of villagers with the state and civil society through structures and ideologies of authority and participation, faith, and identity. Rather than taking away from some abstract universal identity, I show how it is the local Church that makes it possible for individuals to participate as citizens. Contrary to the sense that religious politics occupies a separate sphere from that of the secular, there is in fact an articulation of the politics of the Church to the secular politics of the state, and vice versa. The Catholic Church often draws on the same tropes of development, nationalism and uplift as the state, and the shifts in ideological orientation (right to left to right) within it mirror those in other contexts both international, and national.

5 The empirical core of this paper draws on field work conducted in seven fishing villages in Kanyakumari district of Tamil Nadu in South India over two periods in 1994-1995 and 2004 , and on continuing conversations with diocesan priests and lay people in the years since then. Kanyakumari district borders Kerala and has a sizable Christian minority, though not all of it is Catholic. According to the 1991 census, $42.35 \%$ of the district's population identified as Christian, compared to $19.32 \%$ in Kerala, $5.69 \%$ in Tamil Nadu, and $2.32 \%$ (only $1.7 \%$ of whom are Catholics) in India as a whole. Located at the southernmost edge of the district, are the forty two coastal fishing villages which are the focus of this article. Kurien (2000) has noted that the fishing villages in Kerala prove an aberration to the 'Kerala model' of high literacy and social development; this is equally the case in Kanyakumari, as it is globally (Bene 2003). The fishing castes - Mukkuvar and Paravar - that make up these villages are both categorised as 'Other Backward Classes' in the Indian Constitution, for purposes of affirmative action. Despite their traditional economic and social marginality, these fishing communities have a strong sense of their own identity, stemming from an awareness of their long lineage in the region, pride in their difficult profession, their independence from everyday ritual submission to higher castes, and their conversion to Catholicism in the sixteenth century. Notwithstanding their relative poverty, and the strong identification with place, they are not isolated. They are shaped by a variety of intellectual, social and political influences made possible by their closeness to the district headquarters of Nagercoil, a busy town of some two hundred thousand in 2001, as well as to Thiruvananthapuram, the capital of Kerala; the 
constant flow of tourists to Kanyakumari; the presence of an international institution the Catholic Church; the fishermen's own mobility, both across the country and to the countries of the Persian Gulf; and the villagers' steady consumption of films, television, and now, the Internet.

Although the Catholic Church is an institution of singular importance in the coastal villages of Kanyakumari, there is no single way of understanding its role. It is a key element of the identity of the villagers, the basis of their faith, and an intimate part of their everyday lives and struggles. As Kalpana Ram (1992) has argued, it also functions as a 'quasi-state' in the villages. From the time of the Church's entry here five centuries ago, every state of the day, including that of postcolonial India, has accommodated it, allowed it to take on administrative and judicial functions, and to represent the villagers. The size and prominence of the church in every village, especially when contrasted to the cramped housing of the villagers, illustrates its centrality as a structure of authority. The Church also operates at multiple scales beyond the local: not only as part of a powerful international institution, but at the national scale, as representing a small minority. Catholic faith and identity are deeply rooted and thoroughly indigenised; nevertheless, as an international institution, the Church must constantly struggle between introducing new ideas and directives from the World Church (for instance, around theological purity and liturgical practice), and the need to 'inculturate' 2 and remain indigenous, especially in the context of Hindu nationalism. Nor is the relationship between the local Church and its community entirely harmonious, with its authority being constantly called into question, and many of its own activities being about restoring or trying to maintain legitimacy. Charting the course this struggle has taken over the centuries - between the secular and the spiritual, the international and the national, the institutional and the popular - is necessary to a complex understanding of the Church's present role.

Much of the task of mediation between the different levels outlined above is carried out by individual clergymen, many of whom come from the fishing villages. Drawing on Gramsci's schema (1971: 5-14), this article examines their role as agents of transformation, both as organic intellectuals representing their class, and as traditional intellectuals who articulate the ideology of the Church and state. Attending closely to the background and role of the clergy helps us to compare and counterpose their involvement in politics with similarly placed individuals in Hindu right organisations, most of whom are drawn from the upper castes (Jaffrelot 1996, Saberwal \& Hasan 2006), and for whom the intertwining of religion and politics is a way of keeping other castes and religions down.

8 Church-related associations play another key linking role between the Church and state. Over the years, for reasons having to do locally with needing to maintain legitimacy with its followers, nationally with matching secular movements aimed at social reform, and internationally with movements of contestation and reform, the Catholic Church has introduced a variety of associational forms in the villages. These range from pious associations and youth groups, to the Basic Christian Communities (BCCs) and Parish Councils. They have become spaces from within which the Church struggles to maintain its relevance, and from which parishioners seek to make claims upon the Church and state, while simultaneously asserting their autonomy from them. But they are also spaces within which villagers seek to reform the hierarchies of village life itself, such as the exclusion of women from political authority. Religiosity here is mediated by an awareness of wider Indian tropes of democracy and development, and villagers' ability to negotiate 
between the Church and other patrons such as political parties in order to further their secular interests. Fishers rarely act only as Catholics, but also as members of backward castes, regional and linguistic identities, fisher people, and women. Equally importantly, the associations are spaces where members learn the routines and technologies of modern governance, such as rules of order for the conduct of meetings, minutes and accounts, village censuses, and membership cards.

In the first part of this article, I provide a brief history of the Roman Catholic Church in the region, its key structures, influences and turning points. From the beginning, it was embedded in local politics, establishing parallel structures of justice and revenue collection, while also moulding itself to local caste hierarchies and aiding rulers in their conflict with other powers. In the second section, I look at contemporary efforts by individual clergymen to articulate ideas of reform and development, mediating between their own class, the wider Church hierarchy and the state. The third section looks at villagers' participation in Church-generated civil society associations as spaces where they negotiate between spiritual and secular imperatives, and the shifting alliances this leads to. The article ends with a discussion of the Catholic Church's place in the political community, particularly in relation to democratisation, development and communalism, concluding that we need to think of practices of religiosity and citizenship as not mutually exclusive.

\section{The Catholic Church in Kanyakumari - a brief history}

\section{Origins and early history}

10 A relationship of accommodation and collaboration for mutual benefit was established between Church personnel and the state from the Catholic Church's very beginnings in the region. The fifteenth and sixteenth centuries were a period of enormous political flux, with contending rulers like the Kingdoms of Venad (later Travancore), Cochin, the Pandyas, the Nayak of Madurai, and the Zamorin of Calicut seeking to control both the pearl trade and populations associated with it, and enlisting Portuguese support in this. The Paravars converted in 1536 in exchange for Portuguese protection of their independence in the pearl trade (Bayly 1989: 323-5, Schurhammer 1973-1982: 259, Fernando 1984), while access to the Mukkuvars was enabled by Portuguese support for the Venad king against the Pandyas in 1544 (Narchison et al 1983: 12).

11 Given the tactical nature of the conversions (Bayly 1989: 328), a new religious identity was slow to emerge. The syncretic nature of the emerging religious tradition was exemplified by the growing cult of St Francis Xavier, whom the Jesuits encouraged the Paravars to revere as a supernaturally endowed tutelary figure, exorcist, and healer (Bayly 1989: 330), with features of the Sufi tazkiras (saints' biographies), and of the region's warrior cults. Other pre-Christian traditions endured such as the pulling of a decorated chariot for the feast days of the church, as in a temple festival; and caste histories and oral traditions which relate the Paravars and their rituals to the great Hindu temples of southern Tamil Nadu (Bayly 1989: 330-58). The question of caste hierarchies was contentious from the very beginning. Influential priests such as Robert de Nobili took the position that the maintenance of caste separation (having different churches for different castes, or serving them mass at different times) was necessary for the survival and spread of the Church in the region and had no religious implications. This received papal assent in the 
early 1600s, while later Popes overturned it as a religious sacrilege. In practice, separate churches were constructed for the inland Nadars and the coastal Mukkuvars and Paravars; in some churches a wall was erected to separate seating areas for the higher and lower castes (Roche 1984, Subramanian 2009: 49-50).

Parochial governance increasingly relied on the fusion between the group's caste institutions and their identity as Roman Catholics. The Roman Church had been allowed by the Raja of Venad to arbitrate in civil and criminal matters for its members. Xavier and subsequent missionaries used the village leaders as a kind of moral police against drunkenness, adultery, idolatry, and other transgressions. Portuguese colonial authorities confirmed these powers, using the local leaders' authority to recruit and discipline Paravar divers and others necessary to a productive fishery (Bayly 1989). The missionaries also introduced new structures of administration, appointing a judge and a policeman in every village, and themselves adjudicating more serious cases (Thekkedath 1982: 189). Lay involvement in running the parish and in ministry was solicited from the outset to make up for the shortage of priests; the first pious association, the Confraternity of Charity, was set up some twenty years after the Paravar conversions (Thekkedath 1982: 167-73). Although the kings of Venad, Quilon and Cochin contributed to the erection of churches in their territory, and for a while to their maintenance, and the Portuguese Governor during Xavier's time paid an annual sum to support the missionaries (Schurhammer 1973-1982: 462-3, Xavier 1992: 124 n.11), the lay officers were maintained, the bulk of the churches constructed, and, in later years, the priests supported, through taxes on the fishery in each village. A variety of levies were imposed, to the extent that the Portuguese priests were commonly referred to as kuthagaikkara samigal [levy-priests] (Sivasubramanian 1996).

The new religious identity worked not only to create cohesion in the caste and enable it to manoeuvre more efficiently for status vis-à-vis other castes and the rulers, but also to bargain with the Church hierarchy itself. By the 1830s the Jesuits found that caste notables could decide what sacraments each family was permitted (Bayly 1989: 360-1). In the Jesuits' campaign to regain control over these decisions, they drew on the support of disaffected mejaikarar [white-collar] families, and even kamarakarrar [fishing] families who had grown rich on trade but did not have ceremonial status in the village. But the leading families were likewise able to retaliate by exploiting the schisms within the Church, threatening to shift to new affiliations like the Protestant London Missionary Society, ${ }^{3}$ or even threatening to leave the fold (Bayly 1989: 316-8). In other cases, the less powerful villagers also organised against the hierarchy, including the parish priest, using allegations of financial or moral corruption to call on the Bishop to replace their priest, threatening conversion if he failed to do so.

14 In 1930, the new diocese of Kottar was erected by papal decree from the southern and Tamil-speaking part of the diocese, and entrusted to the indigenous diocesan clergy (Villavarayan 1956: 34). The Church was one of the few avenues for social mobility in the villages and many Mukkuvars became clergy. The new diocese moved rapidly to reform some of the most hated elements of Church governance in the villages, and with more limited success, to strengthen a more doctrinal Catholicism against the forms of popular devotion that were central to religious practice in the region, such as shrines to St. Antony and other saints to cure possession and other ailments. One of the earliest reforms was to the kuthagai system of revenue generation for the coastal parishes, based entirely on levies on the fishery. Following sustained campaigns by fishing families, intra- 
village divisions between pro- and anti-levy factions, and the conversion by a group of anti-levy Paravar to Hinduism (Sivasubramanian 1996), the diocese eventually took steps to curb expenditure and redistribute levies to all village residents (Villavarayan 1956: 52).

India's independence led to new developments in the national Church. The understanding of secularism implicit in the constitution of the new Republic of India (and made explicit in a 1976 constitutional amendment describing India as a 'secular' republic), was one of 'equal respect for all religions', rather than a distancing from religion altogether. However, secularism as the increasing desacralisation of life remained a powerful aspiration for modernising leaders like Nehru. This posed new challenges for the Indian Church, given that opposition to secularisation was a key principle of the Church's involvement in politics across the world, along with opposition to communism (Houtart 1984). In the second general elections in 1957, for example, the Catholic Bishops Conference of India ( $\mathrm{CBCI}$ ) issued a statement which was read in all churches, asking Catholic electors not to support candidates who were against religion, morality, and the sanctity of family life. In the following elections too, Catholics were asked by the Tamil Bishops not to vote for the communists or the social reformist Dravida Munnetra Kazhagam (DMK), as both were opposed to religion. In general, the Catholic Church in Tamil Nadu was, for the first decades after independence, explicitly in favour of the (Indian National) Congress (Narchison et al 1983: 94-5, 115-6). It also expanded its longstanding work in education and health in this period, cooperating with the government in these areas (Wilfred 1981: 829).

\section{The Second Vatican Council (1962-1965)}

The election of Pope John XXIII in 1958, and the holding of the Second Vatican Ecumenical Council in 1962, marked a major change in the Catholic Church's understanding of its role in the polity. Historically, society, Church, and state were considered organically interlinked, with political authority seen as ultimately derived from God. The Vatican II documents express an acceptance of religious, social, and political pluralism, a constitutional state, and the principle of freedom of the Church in society (Hehir 1993: 22). The result of Vatican II at the national and local level was greater lay participation, both in parochial administration and in the liturgy. This was to be facilitated by new structures of administration, such as the Parish Councils, and new pastoral strategies, such as the Basic Ecclesiastical Communities. In addition, there was new theological reflection, best known in the Liberation Theology of Latin America, but also elsewhere, as in the Contextual Theology of South Africa (Lehmann 1996: 49, Littwin 1989). The idea of social ministry - the understanding that the work of the Church is the defence of the person - became central. This was to be performed, not through direct political involvement, as in the standing of clergy or religious for office, but through social activism.

The ideas of Vatican II interacted with indigenous movements and currents of social reform emerging across Latin America and the decolonising nations of Asia and Africa (Lehman 1996: 13-4). An Indian theology of liberation emerged from theologians such as George Soares-Prabhu (1929-1995), M.M. Thomas ${ }^{4}$ (1916-1996), and Sebastian Kappen (1925-1993) (Kappen 1986: 305). It was cross-pollinated by Gandhian tropes of indigenous development; in the early 1970s by the ideas of Naxalbari and the Jayaprakash Nararyan movement, both of which challenged, albeit in different ways, the class bias of the Indian 
development model; and by the emergence of a voluntary sector (Shah 1988). But Indian liberation theology was unique in being forced to grapple from the outset with India's multi-religious society. Here, the true community of Christ, if it was to offer the promise of transforming social structures, must necessarily be larger than the Christian community. As Kappen (1986: 310-31) wrote: '[T] he stirrings of a new theology can be found only among theologians and such Christian groups who have broken loose, at least mentally if not also physically, from the ghettos of church institutions and have cast anchor in the secular world.'

In Kottar, some of these shifts had already begun with the arrival in 1950 of the Belgian priest, Fr James Tombeur (1924-2002), of the Society of the Auxiliaries of the Missions (SAM), who lived and worked in Kottar until his death. His efforts led to the formation of the Kottar Social Service Society (KSSS) in 1963, which over the decades took up numerous activities, such as a community health development project, cottage industries, and cooperatives for fishermen and farmers. Of the KSSS, he wrote: 'from the start [it] was people-oriented and low priority was given to relief and to institutions like schools, convents and so on. The inspiration was taken from the Gandhian type of development: village-centred, cottage and village industries, providing employment to all and trying to be self-supporting' (Tombeur 1990: 41). Tombeur's work also prefigured many of the themes of inculturation ${ }^{5}$ and lay participation emphasised by Vatican II. The churches he helped build in the small, remote inland communities in which he served as parish priest in the 1950s were the first (and still the only) local churches in the Dravidian style, rather than the standard pseudo-Gothic (Collins 2007: 128-9).

Following Vatican II, these innovations began to be taken up across the diocese in the form of: liturgical renewal; emphasis on the Bible and on catechism; inculturation, through the mass now being said in Tamil, and other local elements of worship added to the liturgy; lay participation - in the mass, as in the celebrant facing the congregation and in ministry, such as through pious associations; new structures for pastoral administration, as well as for social awakening and involvement; and the taking of more critical positions on social justice. Leading diocesan priests expressed a growing sense that even developmental works might not be radical enough:

The developmental works of KSSS, commendable though in themselves, are they not still becoming unwittingly agents of alienation? Do they not deflect the Church from raising fundamental questions about the condition of the society and the structures of injustice at work? The strength of the developmental work can well become the weakness of the Church in Kottar, in the sense that they can make the Church insensitive to the real causes of poverty and underdevelopment and blunt the Christian conscience of its social responsibility. They can make us forget that as Church we are called upon to be catalysts and agents of change in society. This responsibility of every Christian cannot be simply delegated to a developmental organization. (Narchison et al 1983: 229-30)

The spirit of Vatican II remained strong in Kottar even after it waned elsewhere by the early 1980s. A pastoral letter issued by Bishop M. Arokiaswamy in April 1986 traces the problems of the people to the unjust socio-economic structures of feudalism and capitalism and speaks of the danger that religion might legitimise them. Describing various flawed Church models and pastoral approaches adopted in the past, such as the 'traditional' approach, the 'charismatic-prayer' approach, the 'dependence' approach, the 'social service' approach, and the 'extremist' approach (Jeremias 1989: 203), the Bishop 
recommended a new approach, the 'Radical Church' model, which was guided by the gospel vision and aimed to bring about radical change in all spheres.

The action plan for Kottar diocese laid out on the basis of this radical Church approach is truly remarkable (Jeremias 1989: 204-5, and all citations below). It calls upon the Kottar Church to take a stand in support of the various people's movements of workers and the marginalised active in the district, arguing that '[w]e too, if we transcend the limits of our parish, diocese and religion and collaborate with these movements, may accelerate the spread and realization of the values of God's kingdom.' The Church must rally round the progressive parties and trade unions, and engage with Marxist ideology and movements as sharing a common concern with human liberation. Strategies that involve violence are not condemned out of hand; rather, structures that oppress people are seen as violent in themselves. The action plan calls for priests and lay people to work together as equals, and for youth and women to be involved. Political awareness and involvement is seen as a Christian duty, the priests being responsible for fostering it among the laity.

\section{The hardening of identities}

The election of John Paul II as Pope in 1978 saw a retreat from the principles of Vatican II, concurrent with a strengthening of the papacy, and the encouragement of more conservative groups like the Opus Dei (Della Cava 1992, Houtart 1984). This was reflected in the Indian Church, which also exercised greater caution about questions of social justice, a greater emphasis on spirituality, and a re-separation of the notions of development and evangelisation. Even prior to this retreat, the $\mathrm{CBCI}$ had maintained silence, and even tacit support for the Emergency (1975-77), perhaps necessary and inevitable for a minority institution; it spoke out only against the compulsory sterilisations carried out by state agencies in this period. Despite the overall retreat from more radical positions, the commissions (departments) established in this period, such as the Labour Commission, and the Committee for Social Welfare, continued to take strong stands on social justice.

Within Kottar diocese, notwithstanding the startling radicalism of the approach outlined in the Bishop's pastoral letter, 'liberationists' had at no point been the majority of the clergy. Rather, their influence appears to have been due to the leadership of key Bishops and other clergy. However, insofar as there was a clear shift away from liberationist positions by the end of the nineties, the impetus for this was not the outcome of internal contestation, but of shifts in the global Church, and, importantly, of the need to respond to external threats: the rise of Hindu nationalism as a significant political force, and the growing popularity of Protestant Evangelical Churches, even among the Catholic masses.

Although their influence in Kanyakumari never reached the proportions that it did in Latin America (Lehmann 1996), many Catholic villagers were attracted in the nineties to the new Pentecostal Churches (Mosse, 1994a). Their practices of 'sharing' life histories and 'bearing witness' to the moment of revelation were recognised even by radical clergy as providing the individual catharsis and psychological healing that post-conciliar Catholicism, with its emphasis on social change, had turned away from. One response, which may have succeeded in arresting the spread of these churches, was the charismatic movement within the Catholic Church encouraged under Pope John Paul II; its prayer meetings resemble those of the Evangelical movement, with elements such as catchy music, prophetic preaching, and collective cathartic participation. 

this case for the Catholic community as much as for the Church as an institution. Relations between the Catholic fishing communities and their Hindu and Muslim neighbours had not been markedly conflicting. Of the 66 incidents of conflict recorded since 1956 in the police stations covering half the fishing villages, only 21 were between the Christian fishing communities and Hindu or Muslim communities. Of these, only three may be called 'communal', in the sense that by their very nature they invoked religious identity: two were over religious symbols such as the desire of one community to carry out a temple procession through the living quarters of the other; the third was over competition in Panchayat elections. All the others arose from the same 'secular' causes - drunken disorderliness, harassment of women, minor thefts, etc. - as in other inter- or intra-village fights.

While a few conflicts escalated due to political parties inflaming local quarrels in order to secure electoral majorities (Chiriyankandath 1993), the institutional threat came primarily from the rise of Hindu nationalism in the early 1980s, reflected in two watershed events in the district: the government-supported construction of the Vivekananda Rock Memorial on a site claimed also by Catholics as a spot where Xavier had meditated, and an incident at Mondaikadu village in 1982, in which rumours set off a spiral of retaliatory violence between Hindus and Catholics, leading to massive injury, loss and destruction in the coastal villages (Mathew 1983: 417). While there were no subsequent incidents of similar scale in the district, smaller incidents continued to occur, such as the destruction of a church in 1995 (Indian Express 1995, Kottar Newsletter 1995). The BJP's rise to power nationally in the 1990s, and the rising tide of attacks against minority communities across the country in the decade following, contributed to a growing sense of besiegement. This hardened identities to a great extent, but did not do away entirely with syncretic practices, or with villagers' bargaining with the Church hierarchy for secular ends. For instance, in the mid-1990s, when expressing frustration with the local priest, or the diocese more generally, more than one fisherman voiced to me in private a threat (usually rhetorical) to convert; such a conversion of a few families did take place in the neighbouring diocese (Fishing Chimes, 1987). More significantly, in 1995, Catholic trawler owners voted as a group for the BJP, upset that the radical politics of the diocesan Church had led it to favour the small-scale artisanal fishermen over them in their conflicts over space and catch (Subramanian 2009: 228-34).

By the turn of the century, as a result of the conjuncture between a number of imperatives - the need to demonstrate patriotism in the face of Hindu nationalism; gradual conformity with the international Church in its retreat from Vatican II; and the changed understanding of 'development' as market-led growth after India's economic reforms of the early 1990s - the Diocese had reverted to older priorities. These included establishing elite educational and medical institutions, and development work, which now consisted increasingly of microcredit groups for women and various kinds of training programs around health, hygiene, or computer literacy. Nevertheless, 'power from below' and 'breaking the yokes of injustice' remain two of the four basic pillars of the Diocese's stated vision (Diocese of Kottar website), suggesting that liberationist values were not just strategic but, rather, deeply held by a significant number of diocesan clergy. 


\section{The Clergy}

parish priests embody this dual relationship, for they are functionaries of the Church, and also frequently themselves come from the coastal villages. The 275 or so diocesan clergy are drawn from the district's Catholic castes: Nadar, Paravar, and Mukkuvar. Although the inland Nadar priests appointed to coastal parishes are commonly said to have a harder time than Mukkuvar or Paravar priests, virtually every priest regardless of caste had his critics in the village. Rude jokes about their soft hands and clean-shaven faces (in a region where manliness presumes a moustache), and rumours (rarely substantiated) of financial corruption, or intimacy with women, were in constant circulation. The youth wanted dynamic priests with new ideas. Old-timers spoke disdainfully about the younger priests with their casual manners, quick to shed their cassocks, frequently off on their motorcycles to commissions and activities outside. They recalled with nostalgia the ideal priest of an earlier time, distinguished by his pious demeanour and perennial brown cassock, who read the Bible or prayed with the people in his spare time, and rarely left the village. Yet, as seen in the previous section, factions involving the priest, and accusations against him, were as common earlier, especially in the days when the priest also managed the parish funds.

The priest in the coastal parish is called upon to fulfil a variety of functions, unlike in an inland one, where parishioners are more comfortable dealing directly with the civic administration (Narchison et al 1983: 138). In the fishing village, the priest is leader, judge, problem solver, liaison with government, sole representative of the village, preacher, counsellor, and guide (Ram 1992: 40). The work of the priest is not only concrete and practical, but also, as famously observed by Gramsci (1971: 5-16), 'intellectual', that of generating social and political hegemony. There are, increasingly, other intellectuals in the villages, such as social workers, political activists, and NGO staff, but the priests are still the best educated as a group, and, by virtue of their historic preeminence and institutional base, the most authoritative.

Gramsci (1971: 5-16) distinguishes between two types of intellectuals, organic intellectuals and traditional intellectuals. Organic intellectuals are those who arise as a part of every social group or class to give it 'homogeneity and an awareness of its own function not only in the economic but also in the social and political fields'. Traditional intellectuals are those who have always performed the role of intellectuals in society, such as administrators and other state functionaries, scholars, scientists and philosophers; by virtue of their uninterrupted historical continuity as a group and their special qualifications, they consider themselves autonomous of every social class. The Gramscian schema, while productive for this case, cannot be transposed directly across time and space (Arnold 1984, Davidson 1984). Gramsci writes that ' $(\mathrm{t})$ he category of ecclesiastics can be considered the category of intellectuals organically bound to the landed aristocracy', and further that, unlike other social groups, a person of peasant origin who becomes an 'intellectual' (priest, lawyer, etc.) generally ceases thereby to be organically linked to his class of origin, and functions as a traditional intellectual. In India, the Church is both a minority institution and not organically linked to the state, either constitutionally or through its affiliation with the dominant classes, such as the landed aristocracy, and to a large extent represents instead the lower castes. ${ }^{6}$ Despite

South Asia Multidisciplinary Academic Journal , Free-Standing Articles 
these differences, Ram holds that the clergy of Kottar diocese function as traditional intellectuals, sharing with state intellectuals 'a commonly understood vocabulary of reform, rationalism, development and cultural nationalism' (Ram 1995: 293).

31 There is much to Ram's argument, for as seen in the previous section, the social projects of the Kottar Church have frequently paralleled those of the state. As in Lehmann's discussion of basismo ${ }^{7}$ in Brazil, it is possible to see certain common ideological tropes that underlie both religious and secular attempts at social transformation. However, just as basismo represented a new respect for the subaltern, and thus a challenge to the more authoritarian and elitist traditions of Church and state in Latin America, so different currents within the Kottar Church must be seen as existing in some tension and contradiction with each other, and with the state. For instance, although the idea of modernisation informed both state fisheries policy and the interventions of the KSSS, the former resulted in large-scale mechanisation initially accessible only to a handful of villagers, while KSSS interventions through appropriate technology and cooperativisation reached more widely into the villages.

I argue, therefore, that the reformist clergy are in fact drawn to act both as intellectuals of their class, articulating the consciousness of that class, and of the Church and state. Their identification as organic intellectuals is illustrated by the opening words to Fr Jeromias's thesis in pastoral theology: 'The eagerness to search for ways and means to better the conditions of the fisherfolk gushes out of me as I am one who had experienced the stings of poverty from my birth.' In the ideas and aspirations the clergy hold and transmit, and in the variety of pastoral approaches they favour, they mirror the different stages of, and influences in, the universal Church's recent development, its location within the Indian political community, and its local social and cultural embeddedness. This can be seen in the wide range of ideological positions held by the clergy of Kottar diocese, particularly among those working in the fishing communities. These include: i) an exclusive focus on the spiritual aspects of the religion, usually accompanied by the encouragement of works of charity and non-political activities such as youth groups and prayer meetings, family development, and personal 'improvement'; ii) an emphasis on development understood as schools, better housing, cooperatives, and community health programs; iii) an emphasis on political and cultural activism ('social analysis' and political critique) informed by a liberationist theology.

These strands are not always mutually exclusive, and all the priests involve themselves in development works within the village, and other traditional parochial responsibilities. There is nonetheless a tension between the first category of priests, concerned to separate religion from politics, and the other two. What distinguished the priests who took one of the latter two positions, but chiefly the third, broadly influenced by Vatican II and liberation theology, was that they were intellectuals in the commonplace (nonGramscian) sense of the term, being highly educated and frequently engaged in research and writing. Several of them had post-graduate degrees, and most had held important appointments in the Diocese or elsewhere. The diocesan clergy all begin their education in a local minor seminary where they are formed in matters intellectual and spiritual, and also in skills like music, public speaking and acting, before being sent elsewhere to a major seminary for theological studies. There is also a growing tendency for them to be sent to college between minor and major seminary, or to pursue higher studies, often in secular subjects (Narchison et al 1983: 211). Of the group I interviewed, almost all had further studied subjects they believed would assist them in their role as (organic) 
intellectuals and leaders, such as group dynamics and management, public administration, law, media and communication, computers, and counselling.

Working in the coastal parishes, these priests had introduced reforms to break existing power structures, encourage lay leadership, reduce violent conflict, and systematise parochial administration. For instance, Fr Dionysius interacted intensively with individual fishermen to initiate fishermen's cooperatives that would end the power of the merchants; Fr Edwin refused to act as mediator with the administration over complaints, but began, again through painstaking house-to-house visits, to set up participatory administrative structures in his parish that eventually turned into the diocesan Basic Christian Communities program; Fr Servatius sat on a three day fast in the church as a way of ending the factional fighting in his parish. Fr Justus personally surveyed each of the seven hundred houses in his parish in order to issue family cards containing basic household information. He had computerised all parish records of birth and baptism so that they were accessible alphabetically and was working to get individual land titles issued to each family.

In the mid 1990s, some twenty of these priests had formed a group called the 'Coastal Analysis Programme' aimed at studying and strategising around the social problems in the villages. As the group grew, they decided to think of themselves as an enabling group within the Diocese, providing direction and analysis to other organisations, building up a library and documentation centre on coastal issues such as sea erosion, and carrying out reflection on coastal ministry. They began to hold study meetings around issues such as the Indian Government's deep sea fishing (DSF) policy which led to support for strikes against this policy, educational backwardness and violence in the villages, and the design of participatory governance structures. At one of the group's meetings, I observed an extensive discussion on how to work out a program of culture for the villages, the understanding being that certain of the villagers' cultural habits prevented their liberation. Many of those present spoke as 'insiders' to this culture, talking nostalgically of old games and songs that had been lost with the coming of television. Although the group disbanded after a few years, its members' interests became institutionalised in diocesan agencies concerned with new media and the revival of traditional cultural forms.

\section{Lay associations}

In the seventies, the diocesan Church began attempting to reform structures of village governance, prompted partly by the directives of Vatican II, and partly by growing popular resentment against the traditional headmen it had backed. The two main types of organisations introduced in this period were the Parish Councils, and the Basic Christian Communities (BCCs). Villagers' participation in these organisations provides a third layer within which to examine the intersection of religious authority, identity and faith with the secular politics of the village.

The BCCs were brought to Kottar Diocese by Fr Edwin, a Mukkuvar diocesan priest who had grown up in a fishing village. He had been involved with youth movements like the Young Christian Students (YCS) and Young Christian Workers (YCW) at the beginning of his active life, keenly read Marx, and also literature about the base communities ( Communidades Eclesiales de Base, or CEBs) which had emerged in Brazil and other parts of Latin America, post Vatican II (Lehman 1990: 128-9, Levine \& Mainwaring 1989). His first 
parish was notorious for its violent factionalism, making the idea of cross-cutting, neighbourhood based units of participation especially appealing as an alternative. $\mathrm{Fr}$ Edwin began with house visits and sustained interaction with his parishioners between 1977-79, running formation programs on spiritual and socio-economic themes, as well as on topics such as leadership, group dynamics, and the problems of fishermen, carrying out some two hundred days of formation programs for various groups.

The BCCs emerged out of this process. The basic units set up by Fr. Edwin consisted of thirty neighbouring households each, called the anbiam, which in turn sent five people to the general body of the village, one of whom was elected to the executive committee. This was then registered as a society - the Mulu Valarcci Sangam (Total/Integral Development Society) or MVS. The MVS set up various committees such as an education committee, and gave out short term loans. For the first time, the village leadership, including the President's post, was in the hands of the laity rather than the parish priest. A whole new generation of active youth emerged from this process, but it was also met with a great deal of opposition, with many of the past leaders and strongmen resenting their loss of power, and using the increased visibility of women in public life to denounce the new structures as 'alien to the local culture'.

The BCCs were eventually officially adopted by the Diocese in 1984 as the basic units from which representatives were to be elected to the Parish Council. However, their most radical element - institutional autonomy from the Church - was tempered by making the parish priest rather than a lay person, the President of the Parish Council. In practice, the scope of the BCCs varies from village to village, depending in part on the interest of the parish priest and the powers he is willing to cede to them: in some villages they discuss village finances, which give them a great deal of power, in others where this financial control is lacking because of opposition from the better-off fishermen, they function almost solely as prayer groups, and are composed mainly of women and children.

Since the mid-eighties, Parish Councils have been made mandatory in each parish. Parishes which do not have them are not entitled to any diocesan money. Of course, the bulk of village monies continue to be raised from within the village itself, and the Diocese has no means to insist that these flow only through a Parish Council. The Parish Councils act like a village governing body, with rules for membership and elections, the conduct of meetings, constitutional amendments, and representation for different categories of village residents, including women and youth movements, and for key village associations, such as the fishermen's cooperative groups.

of the seven villages I studied, Parish Councils had been successfully established in three; in the remaining four they had been prevented from being set up, or opposition to the BCCs meant that they could not be set up as required through representation from the basic communities; or the Councils were set up, but struggled against opposition and then collapsed. In Kanyakumari village, for instance, the establishment of a Parish Council was resisted, not because of factional differences, or the belligerence of previously dominant families, but because they did not want women leaders. It was argued that women could not take the lead on highly contentious issues in the fishery; there was a sense that physical prowess and backing continued to be important in settling these. It was also feared that a Parish Council would mean that every decision would be subject to review by the Church. Nevertheless, the village committee that governed instead was also elected, and consisted entirely of active fishermen, rather than being formed by nomination from the leading non-fishing families of the village, as in the past. The three 
functioning Parish Councils I observed did indeed follow rules of order. Their meetings were held in the Parish Priest's office, the church, village meeting hall, or school. Matters dealt with by the Council arose from a variety of sources: precedence, ongoing projects, and petitions by villagers. A sample list of such matters, drawn from the three councils, includes expenditure and revenues; development and welfare projects; fishing conflicts; intra-village conflicts, usually factional; relations with other organisations, in the village and outside, such as the fishermen's cooperatives; village services; the school; stopping alcohol sales; and collective support in the lean fishing season for the families belonging to the various service castes (mainly barbers).

The organisations described here - the BCCs and Parish Councils - emerged, not out of internal contestation and change within the villages themselves, but out of broader debates and changes at other levels, such as the Universal Church and the Indian state. While the structures may have been externally conceived, however, it is conditions at the village level that determined their reception, functioning, and survival. The historical compact between Church and state which gives the former relative autonomy to oversee law and order, development, and finance in the villages has some merit, for the state lacks the ability to work through overlapping and networked structures based close to the lifeworld, such as the Basic Communities, pious associations, and youth groups. Nor is it willing to invest resources and personnel in the kind of close and sustained attention to formation seen here, in the efforts of parish priests such as Fr Edwin, for instance. Political parties have managed to make some inroads, linking up to factions, or creating their own youth and women's wings, but they too lack the Church's access to the lifeworld of the villages, and nor do they represent the villages in their entirety as the Church does.

It has been argued that, as bodies aimed at democratising the Church, the power and the promise of the CEBs in Brazil was greatest when they had no legal or religious status and remained informal bodies, that is, when they represented a real alternative to the Church hierarchy (Lehmann 1990: 131). This was not the case for long in Kottar, because the BCCs early on became an official Commission of the Diocese, with central rules and templates; they were further integrated into diocesan administration when they were made the basis of the Parish Council. On the other hand, there seems to be consensus among observers of the Latin American CEBs (Lehmann 1996, 1990, Adriance 1995, Levine \& Mainwaring 1989), that their success depended very much on the presence of supportive priests or nuns, and on support from the local hierarchy, so that they were never completely autonomously generated and sustained spaces for lay participation. In this sense, the Kottar BCCs are no different. Given this, we may question the extent to which the BCCs had a radical impact on the nature of Church authority in the villages. Lehmann's (1996: 76) argument might certainly apply here: 'This paradox of an antihierarchical movement depending for its survival on the hierarchy itself,' had the effect of blunting the possibility of genuine transformation of the Church.

However, one must look beyond the democratisation of the Church to judge the true significance of these organisations. In her ethnography of these villages, Subramanian (2009: 250-2) argues that villagers' negotiations with the Church, other powers, and the modern state, reveal a long history of claims-making with its own vernacular forms, one of which is the seeking of alternative patrons. She resists the idea that rights and democracy might have a European or specifically modern provenance, and seeks instead to 'provincialise' them. While I am sympathetic to this aim, I see the establishment of 
liberal democratic institutions and processes under the postcolonial state as having enormous consequence for a new vocabulary of claims-making, as well as for new technologies of governance. The associations described here reflect the politics of the reformist Church, but also the deep influence of the ideas of social equality, and democracy as participation in governance, contained in India's liberal-democratic constitution (Mosse 1994b).

While the associations described here were initiated by the Church, participants do not simply accept its authority. What we see instead is a struggle between the Church, the village community, traditional village leaders, and hitherto marginalised groups such as youth and women. What becomes clear is that individual, gender, and class interests are emerging to challenge the traditional identities of village and Church community. Participation is directed at transforming society itself. We also see a widening of the will to self-governance, and the routinisation of the procedures and technologies of modern governance. This can be seen in the insistence that all members of the community have equal claims to participate, and that leaders, even at the village level, should be elected. A self-conscious modernity may also be seen in the manner in which meetings are conducted, with rules of order, minutes, and formal agendas. Various technologies of (self-) governance are beginning to be adopted, such as village censuses and the computerization of village records; family cards indicating membership in the village; and the assignment of individual land titles to land previously held in common in order to allow villagers to apply for bank loans. It may be that, as Lehmann (1996) has argued regarding the Brazilian CEBs, the deeper impact of these associations has been to serve as mediums of modernity.

\section{Conclusion}

Religion acts variously: as an essential element of identity; as a matter of private faith; and as the basis for social critique and reform. Examination of this phenomenon at three levels - the national Church and Diocese, the clergy, and the laity - provides both an institutional and a political economy perspective on the role of religion in politics, undermining assumptions that it acts in any essential way.

The evolution of the Catholic Church has mirrored developments at the various scales into which it enters: the universal Church, the Indian political community, and the local social and cultural community within which it is embedded. Even at each of these scales, there is considerable heterogeneity, as the reversals following Vatican II, or the always contested status of Liberation Theology, suggest at the scale of the global institution. At the national and local scales, both for its faithful, and for others, it embodies a variety of meanings including faith, identity, and governance. It has had to steer a careful course between these multiple scales and diverse meanings. It has had to accommodate to the state and carry out governance functions in order to strengthen itself as an institution, while seeking to retain an always restive congregation. It has had to cultivate and maintain a distinct identity, characterised by a unique tradition of worship, while resisting attempts to cast it as alien and non-indigenous. It has had to fulfil both the spiritual and the secular needs of its followers. And it has had to resist the secularisation of society, in the sense of a withdrawal of religion from the public sphere, while welcoming state secularism in the sense of constitutional protections for all religions. 

such as those contained in accusations of corruption, or priests' relationships with women. The difficulties of maintaining legitimacy are linked in part to the nature of the religious identity of the coastal Catholics. This was always a somewhat fluid construct, incorporating tropes and symbols from existing religious traditions, and retaining social features such as caste. Conversion, real or threatened, has over the centuries been used as a bargaining tool with the institution. Dissatisfaction with the social reading of religion introduced by Vatican II led some parishioners to transfer to Pentecostal churches. Despite the threat of Hindu nationalism Catholic trawler owners voted for the Hindu nationalist BJP to indicate displeasure with diocesan policies favouring the small-scale fishers. Each of these moments of dissent sparked a revision of course by the hierarchy. The hierarchy's own values and practices are fluid and open to multiple influences. Following Vatican II, there was increased interest by progressive theologians and clergy in using 'Indian concepts and traditions of worship'. The rise of Hindu nationalism in the last two decades has had the effect of hardening religious identities, yet Church and secular intellectuals have continued to share values of development, reform, and uplift. Thus the alliances between the state, the institutional Church and its members, and the wider community, continue to be tactical and frequently shifting.

As part of its faith, and as part of its effort to retain control over its members, the Church has resisted secularisation in the sense of the withdrawal of religion from the public sphere and the reduction of religion to a private matter. However, secularism as constitutional protection for all religions, has been interpreted by state officials to mean a representative role for the institutional Church in all matters representing Indian Catholics (or, in Kanyakumari, all matters referring to the fishing villages), and in this sense, it has been welcomed by the Catholic Church, ${ }^{8}$ for it has served to reinforce the sense of a natural and uncontested unity between the institution and its members. A stronger challenge to this understanding of secularism as mutual accommodation was posed by Vatican II. On the one hand, the move to decentralise Church decision-making to the national and regional levels, the emphasis on pluralism between Church and state, and inculturation and diversity of practices of worship, allowed the Catholic Church to 'integrate' more explicitly within Indian society. On the other, priests inspired by Vatican II's emphasis on social justice, and the theological turn to liberation, sought to interpret their religion politically. In doing so they confronted more explicitly the hierarchies of the state and the arrangements of mutual accommodation that underlay its 'subcontracting' of authority to the Church. But by reinterpreting the faith to make it speak to urgent social realities, they sought simultaneously to reaffirm its value and relevance for the vast numbers of the faithful.

As an institution of civil society, the Church represents the polyvalence of the sphere (Casanova 1996). On one side, it carries out several of the functions of the state, both those that are directly administrative and those that have the function of generating hegemony for its values of development, democracy as institutionalised participation, and secularism as equal treatment. At the same time, struggles within the Church challenge these hegemonic understandings. Against development as modernisation, they pose development as social justice; against democracy as institutionalised participation, they encourage more radical and open-ended conceptions of democracy; and against secularism as equal respect for all religious institutions and practices, they seek to infuse and transform the public sphere through a critical and political reading of Christ's 
message. It may be possible to conclude then that certain forms of public religious practice are not incompatible with what Needham and Sunder Rajan (2007: 33) describe as 'the analogues and constituents of secularism: reason, 'mere reasonableness', rationalism, pluralism, tolerance, law, multiculturalism, minority rights, democracy, liberalism.'

\section{BIBLIOGRAPHY}

Archer, Robin (2001) 'Secularism and Sectarianism in India and the West: What are the real lessons of American History?', Economy and Society, 30 (3), pp. 273-287.

Adriance, Madeleine Cousineau (1995) Promised Land-Base Christian Communities and the Struggle for the Amazon, Albany: State University of New York Press.

Agur, C.M. (1990) Church History of Travancore, New Delhi \& Madras: Asian Educational Services, [1903].

Anandhi, S. (1995) 'Collective Identity and Secularism: Discourse of the Dravidian Movement in Tamil Nadu', in Rudolph C. Heredia \& Edward Mathias (eds.), Secularism and Liberation: Perspectives and Strategies for India Today, New Delhi: Indian Social Institute, pp.176-198.

Arnold, David (1984) ‘Gramsci and Peasant Subalternity in India', The Journal of Peasant Studies, 11 (4), pp. 155-184.

Bayly, Susan (1989) Saints, Goddesses and Kings: Muslims and Christians in South Indian Society 1700-1900, Cambridge: Cambridge University Press.

Bene, Christophe (2003) 'When Fishery Rhymes with Poverty: A First Step Beyond the Old Paradigm on Poverty in Small-Scale Fisheries', World Development, 31 (6), pp. 949-975.

Bhatt, Chetan (2001) Hindu Nationalism: origins, ideologies and modern myths, Oxford: Berg. Bhargava, Rajeev (2007) 'The Distinctiveness of Indian Secularism', in T.N. Srinivasan (ed.), The Future of Secularism, New Delhi: Oxford University Press, pp. 20-53.

Bhargava, Rajeev (ed.) (1998) Secularism and its Critics, New Delhi: Oxford University Press.

Casanova, Jose (1996) 'Global Catholicism and the Politics of Civil Society', Sociological Inquiry, 66 (3), pp. 356-373.

Chiriyankandath, James (1993) 'Communities at the Polls: Electoral Politics and the Mobilization of Communal groups in Travancore', Modern Asian Studies, 27 (3), pp. 643-665.

Collins, Paul M. (2007) Christian Inculturation in India, Aldershot (Hampshire): Ashgate.

Davidson, Alistair (1984) 'Gramsci, the Peasantry and Popular Culture', The Journal of Peasant Studies, 11 (4), pp. 139-153.

Della Cava, Ralph (1992) ‘Vatican Policy, 1978-90: An Updated Overview’, Social Research, 59 (1), pp. 169-199.

Diocese of Kottar website, http://www.kottardiocese.org/ accessed 21 October 2011. 
Femia, Joseph (1975) 'Hegemony and Consciousness in the Thought of Antonio Gramsci', Political Studies, 23 (1), pp. 29-48.

Fernando, S.Verantius (1984) 'The Portugese Patronage (Padroado) and the Evangelisation of the Pearl Fishery Coast', Indian Church History Review, 18 (2).

Fishing Chimes (1987) '22 fishermen families of Koothankuli return to Hindu fold', December.

Freedman, Amy L. (2009) 'Political Viability, Contestation and Power: Islam and Politics in Indonesia and Malaysia', Politics and Religion, 2, pp. 100-127.

Gorski, Philip S.; Altinordu, Ates (2008) ‘After Secularization?' Annual Review of Sociology, 34, pp. 55-85.

Gramsci, Antonio (1971) 'The Intellectuals', 'Notes on Italian History', 'The Modern Prince', 'State and Civil Society', in Q. Hoare \& G.N. Smith (eds.), Selections from the Prison Notebooks, London: Lawrence and Wishart.

Hasan, Mushirul; Saberwal, Satish (eds.) (2006) Assertive Religious Identities, Delhi: Manohar.

Hehir, Bryan J. (1993) 'Catholicism and Democracy: Conflict, Change and Collaboration', in John Witte (ed.), Christianity and Democracy in Global Context, Boulder (Connecticut): Westview Press, pp.15-30.

Houtart, Francois (1984) 'Religion and Anti-Communism: The Case of the Catholic Church', Socialist Register, 21, pp. 349-363.

Indian Express (1995) 'Attempt to Storm Church by Kar Sevaks Thwarted', 27 March.

Jaffrelot, Christophe (1996) The Hindu Nationalist Movement and Indian Politics, New Delhi: Viking.

Jeremias, George (1989) Pastoral Ministry among Fishermen in the Diocese of Kottar with Special Reference to Poverty, Ph.D. dissertation, Rome: Pontificia Universitas Lateranensis.

Kappen, Sebastian (1986) ‘Towards an Indian Theology of Liberation', in Paul Puthanangady (ed.), Towards an Indian Theology of Liberation, Bangalore: Indian Theological Association and National Biblical, Catechetical and Liturgical Centre, pp. 301-318.

Kottar Newsletter (December 1994-January 1995) ‘The Manalikuzhivilai Church Issue', 61/62.

Kurien, John (2000) 'The Kerala Model: The Central Tendency and the 'Outlier', in Govindan Parayil (ed.), Kerala: The Development Model: reflections on sustainability and replicability, London and New York: Zed Books, pp. 178-197.

Lehmann, David (1990) Democracy and Development in Latin America: Economics, Politics and Religion in the Post-War Period, Philadelphia: Temple University Press.

Lehmann, David (1996) Struggle for the Spirit: Religious Transformation and Political Culture in Brazil and Latin America, Cambridge: Polity Press.

Levine, Daniel H.; Mainwaring, Scott (1989) 'Religion and Popular Protest in Latin America: Contrasting Experiences', in Susan Eckstein (ed.), Power and Popular Protest: Latin American Protest Movements, Berkeley: University of California Press, pp. 203-240.

Littwin, Lawrence (1989) 'Religions and Revolution: A Brief for the Theology of Liberation', Socialist Register, 25, pp. 264-277.

Madan, T.N. (1998) 'Secularism in its Place', in Rajeev Bhargava (ed.), Secularism and its Critics, New Delhi: Oxford University Press, pp. 297-320. 
Mahmood, Saba (2004) Politics of Piety: The Islamic Revival and the Feminist Subject, Princeton: Princeton University Press.

Mateer, Samuel (188-) The Gospel in South India: or, The Religious Life, Experience, and Character of the Hindu Christians, London: Religious Tract Society.

Mathew, George (1983) 'Hindu-Christian Communalism: An Analysis of the Kanyakumari Riots', Social Action, 33, pp. 407-419.

Mosse, David (1994a) ‘The Politics of Religious Synthesis: Roman Catholicism and Hindu Village Society in Tamil Nadu, India', in Charles Stewart \& Rosalind Shaw (eds.), Syncretism / AntiSyncretism: The Politics of Religious Synthesis, London \& New York: Routledge, 1994, pp. 85-107.

Mosse, David (1994b) 'Idioms of Subordination and Styles of Protest among Christian and Hindu Harijan Castes in Tamil Nadu', Contributions to Indian Sociology (n.s.), 28 (1), pp. 67-106.

Nandy, Ashis (1998) 'The Politics of Secularism and the Recovery of Religious Toleration', in Rajeev Bhargava (ed.), Secularism and its Critics, New Delhi: Oxford University Press, pp. 321-344.

Narchison, J.R.; Francis, E.; Paul Leon, V.; Wilfred, F. (1983) Called to Serve: A Profile of the Diocese of Kottar, Nagercoil: Bishop's House.

Needham, Anuradha Dingwaney; Sunder Rajan, Rajeswari (eds.) (2007) The Crisis of Secularism in India, Durham \& London: Duke University Press.

Nigam, Aditya (2006) The Insurrection of Little Selves: the Crises of Secular-Nationalism in India, New Delhi: Oxford University Press.

Ram, Kalpana (1992) Mukkuvar Women: Gender, Hegemony and Capitalist Transformation in a South Indian Fishing Community, New Delhi: Kali.

Ram, Kalpana (1995) 'Rationalism, Cultural Nationalism and the Reform of Body Politics: Minority Intellectuals of the Tamil Catholic Community', Contributions to Indian Sociology, 29 (1-2), pp. 291-318.

Roche, Patrick A. (1984) Fishermen of the Coromandel, New Delhi: Manohar.

Schurhammer, Georg (1973-1982) Francis Xavier, His Life, His Times, Rome: Jesuit Historical Institute.

Shah, Ghanshyam (1988) 'Grass-roots Mobilization in Indian Politics', in Atul Kohli (ed.), India's Democracy: An Analysis of Changing State-Society Relations, Princeton: Princeton University Press, pp. 263-304.

Shorter, Aylward (1988) Toward a Theology of Inculturation, London: Geoffrey Chapman.

Sivasubramanian, A. (1996) 'Fin-Levy' (Thuvik Kuthagai) Agitation in Idinthakarai, Tamil Nadu 1964-67', South Indian Studies, 2, pp. 260-271.

Srinivasan, T. N. (ed.) (2007) The Future of Secularism, New Delhi: Oxford University Press. Subramanian, Ajantha (2009) Shorelines: Space and Rights in South India, Stanford: Stanford University Press.

Tejani, Shabnum (2008) Indian Secularism: A Social and Intellectual History, Bloomington: Indiana University Press.

Thekkedath, Joseph (1982) 'The Christian Communities of the Coastal Regions of Tamil Nadu (1542-1700)', in Joseph Thekkedath, History of Christianity in India, Vol. 2, Bangalore: Theological Publications India for the Church History Association of India, pp.154-272. 
Tombeur, James (1990) Led by God's Hand: Reflections on My Faith Experience and Pastoral Ministry, Trivandrum: Nalini Nayak.

Villavarayan, J. (1956) The Diocese of Kottar: A Review of Its Growth, Nagercoil: Assisi Press.

Wilfred, Felix (1981) 'The Social Orientation of the CBCI (1944-1980)', in D.S. Amalorpavadass (ed.), The Indian Church in the Struggle for a New Society, Bangalore: National Biblical, Catechetical, and Liturgical Centre, pp. 827-862.

\section{NOTES}

1. Mosse's (1994a) work on Ramnad district in Tamil Nadu makes some of the same arguments, with a greater focus on the ritual sphere, and less attention to the role of the clergy and popular associations.

2. 'Inculturation', defined as 'the on-going dialogue between faith and culture or cultures' (Shorter 1988: 11), is a term and concept that gained currency in the 1960s following Vatican II. But 'accommodation' to local cultures, or in the Indian case, 'Indianisation', has a long history within missiology. See also Collins 2007.

3. If the LMS had limited reach, it was not only because of the defence put up by the Catholic Church, but also because the LMS themselves were more interested in the inland low castes (Subramanian 2009: 53, Agur 1903: 70).

4. That M.M. Thomas was a member of the Mar Thoma Church, rather than the Catholic, reflects the ecumenism of Indian liberation theology. For the origins of the Mar Thoma Church, see Bayly 1989: 312-20.

5. Fr James was deeply influenced by Fr Vincent Lebbe (1877-1940), a Belgian missionary in China in the early twentieth century, for whom inculturation (then referred to as 'accomodation') was about adopting the culture not of the elites but of the popular classes, and about aligning with them against colonial power and racism.

6. This is not uniformly true across the country - the earliest Christians, of the Syrian and Malankara churches in Kerala, are large landowners and historically close to the Travancore and Quilon rulers; Portuguese missionising in Goa also yielded a more Brahmin and upper-caste catch than in southern India.

7. Influential social current of belief that the people, the 'grassroots', have a distinctive culture and outlook on life and society and that political and religious salvation necessarily involves listening to them and gaining empathy with their culture (Lehman 1996: 13-4).

8. Not all attempts at equal treatment have been welcomed. In 1994, Jayalalitha, the Chief Minister of Tamil Nadu, issued a series of pictures of herself depicting various Hindu goddesses. Her attempt at 'equal treatment', involving her portrayal as the Virgin Mary, only served to provoke state-wide demonstrations by enraged Catholics.

\section{ABSTRACTS}

This article re-opens the debate on secularism in India by looking at a religion and a region that has historically been marginal to this discourse, focusing on the way in which the Catholic 
Church has historically mediated the relationship between individuals and the state, among the fishing communities of South India. The Catholic Church's dominant position among the fishing communities, its minority status within India, as well as theological and other shifts that have taken place within the global Church, lead it to articulate a secular, even radical politics as its primary mode of religious engagement. Radical clergy, many from fishing backgrounds, act as both organic and traditional intellectuals in the Gramscian sense, linking the traditional religious concerns of the Church to the secular interests of their parishioners. Likewise, villagers participate in Church-generated associations spaces to secure wider political goals. The paper concludes that certain forms of religious organisation in the public sphere might indeed be compatible with democracy, citizenship, and even secularism.

\section{INDEX}

Keywords: caste, Catholic Church, Christianity, citizenship, clergy, democracy, Gramsci, minorities, secularism

\section{AUTHOR}

\section{APARNA SUNDAR}

Assistant Professor, Ryerson University, Toronto 